\title{
The local site response for upgrading the existing buildings against seismic hazard
}

\author{
A. Ferraro, S. Grasso, M. R. Massimino, M. Maugeri \& E. Motta \\ Department of Civil Engineering and Architecture, \\ University of Catania, Italy
}

\begin{abstract}
The analysis of seismic ground response at the site was conducted using a numerical method, which is developed in three main phases: the definition of the geometric, geological and geotechnical model of the subsurface, the definition of the seismic input, the choice of one or more computer codes to use and the processing of the results. The reconstruction of the geological and geotechnical model of the subsurface has highlighted a morphology quite irregular especially with regard to the covers. In order to assess the effects due to the local stratigraphy, it has been decided to carry out seismic 1-D response analyses, using the computer codes EERA and STRATA. The 1-D analysis was also used for the calibration of computer codes by the modelling of simplified systems and comparing the results obtained by the different codes in order to verify its adequacy. The site response analyses have been developed for some sites in the city of Catania (Italy). On the sites some strategic buildings are localised to upgrade against seismic risk. In situ investigations were carried out in order to determine the soil profile and the geotechnical characteristics for the sites under consideration, with special attention given to the variation of shear modulus and damping with depth. Seismic Dilatometer Marchetti Tests (SDMT) have been carried out, with the aim of evaluating the soil profile of shear wave velocity (Vs). Moreover the following investigations in the laboratory were carried out on undisturbed samples: Resonant Column tests; Direct shear tests; Triaxial tests. The available data obtained from the Seismic Dilatometer Marchetti Tests results enabled us to evaluate the shear modulus profile.
\end{abstract}

Keywords: seismic geotechnical hazard, vulnerability of physical environment, scenario earthquakes, local site effects, INGV Catania site. 


\section{Introduction}

The city centre of Catania, which is recognized as a typical Mediterranean city at high seismic risk, was investigated by in situ tests, including also Seismic Dilatometer Marchetti Test (SDMT). Seismic amplification of the ground motion phenomena were reported by historical sources following the $1693(\mathrm{Ms}=7.0$ $\left.7.3, \mathrm{I}_{0}=\mathrm{X}-\mathrm{XI} \mathrm{MCS}\right)$ and $1818\left(\mathrm{Ms}=6.2, \mathrm{I}_{0}=\mathrm{IX} \mathrm{MCS}\right)$ Sicilian strong earthquakes [1-4] (Figure 1). The most significant features seem to have occurred in the Catania area, situated in the meisoseismal region of both events. These effects are significant for the implications on hazard assessment mainly for the central part of the city, where most facilities are located. The Val di Noto earthquake of January, 111693 is the best remembered by Sicilians. The shock of January 11 which developed from the epicentre (situated at sea but not far from the coast) measured XI on MCS [5, 6] (see figure 1). The Etna earthquake that took place on February 20, 1818 was one of the feeblest ever occurred but its effects were noticed over a vast area. This event as a whole show that the quake reached the peak of IX on MCS [7] (see figure 1). The isoseismal map explains that the earthquake was perceived almost in every part of Sicily from Siracusa to Noto and Palermo. In order to study the dynamic characteristics of soils in the Catania city centre, laboratory and in situ investigations have been carried out to obtain soil profiles with special attention being paid to the variation of the shear modulus $(G)$ and damping ratio (D) with depth. Seismic Dilatometer Marchetti Tests (SDMT) have been also carried out in the zone of the historical city centre, Piazza Roma, where the case study building of National Institute of Geophysics and Volcanology (INGV) is located, with the aim of an accurate geotechnical characterisation, evaluating also the soil profile of shear wave velocity (Vs), as well as the profile of the horizontal stress index $\mathrm{K}_{\mathrm{D}}$. Moreover, the following investigations in the laboratory were carried out on undisturbed samples: Resonant Column tests; Direct shear tests; Triaxial tests.

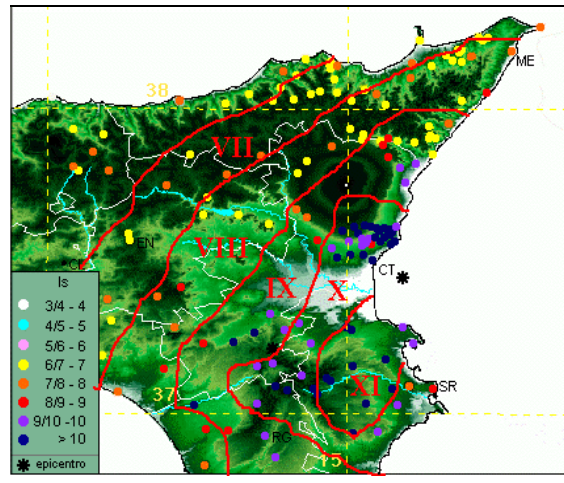

(a)

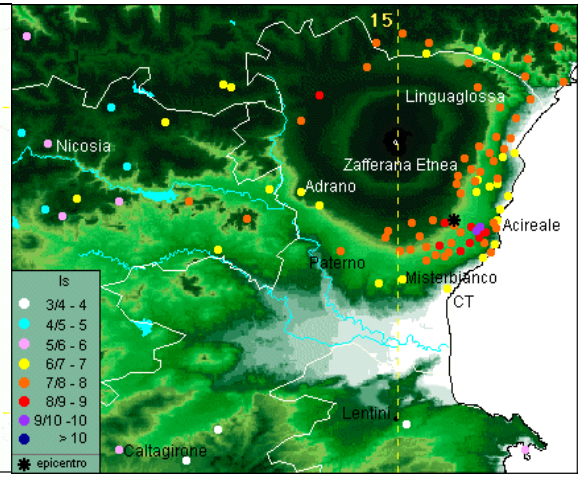

(b)

Figure 1: Isoseismal maps with shocked localities. (a) Earthquake of January 11, 1693; (b) Earthquake of February 20, 1818 (after [4], modified.) 


\section{Geotechnical characterisation by SDMT tests}

To evaluate the geotechnical characteristics of the soil, the following in situ and laboratory tests were performed at the Catania test site: $\mathrm{N}^{\circ}$. 1 Seismic Dilatometer Tests (SDMT); $\mathrm{N}^{\circ} .1$ Cross-Hole Test (C-H); $\mathrm{N}^{\circ} .1$ Down-Hole Test (D-H); No 3 boreholes, Direct Shear Tests; Triaxial CD Tests; Resonant Column Tests (RCT). The investigation programme was performed in the zone of Piazza Roma in Catania city centre. The Seismic Dilatometer Test (SDMT3) has an effective depth of about $35 \mathrm{~m}$. Figure 2 shows the prospect of the building INGV. Figure 3 shows the location of the three boreholes, where have been also retrieved undisturbed samples. Figure 4 shows the location of the SDMT in the Catania city centre. The SDMT [8-10] provides a simple means for determining the initial elastic stiffness at very small strains and in situ shear strength parameters at high strains in natural soil deposits. Source waves are generated by striking a horizontal plank at the surface that is oriented parallel to the axis of a geophone connects by a co-axial cable with an oscilloscope [11, 12]. The measured arrival times at successive depths provide pseudo interval Vs profiles for horizontally polarized vertically propagating shear waves. The small strain shear modulus $\mathrm{G}_{0}$ is determined by the theory of elasticity by the well known relationships: $\mathrm{G}_{0}=\rho \mathrm{Vs}^{2}$ where: $\rho=$ mass density. SDMT obtained parameters are: $\mathrm{I}_{\mathrm{d}}$ : Material Index; gives information on soil type (sand, silt, clay), figure 5(a); M: Vertical Drained Constrained Modulus, figure 5(b); Cu: Undrained Cohesion, figure 5(c); Phi: Angle of Shear Resistance, figure 5(d); $\mathrm{K}_{\mathrm{D}}$ : Horizontal Stress Index, figure $5 \mathrm{e}$ (the profile of $\mathrm{K}_{\mathrm{D}}$ is similar in shape to the profile of the overconsolidation ratio OCR. $K_{D}=2$ indicates in clays $\mathrm{OCR}=1$, $\mathrm{K}_{\mathrm{D}}>2$ indicates overconsolidation. A first glance at the $\mathrm{K}_{\mathrm{D}}$ profile is helpful to "understand" the deposit); $\mathrm{V}_{\mathrm{s}}$ : Shear Waves Velocity, figure $6(\mathrm{a}) ;\left(\mathrm{G}_{0}=\rho \mathrm{Vs}^{2}\right)$ Small Strain Shear Modulus, figure 6(b). The "INGV site" site at the city centre of Catania is characterized by sandy silts with silty clays at greater depths.

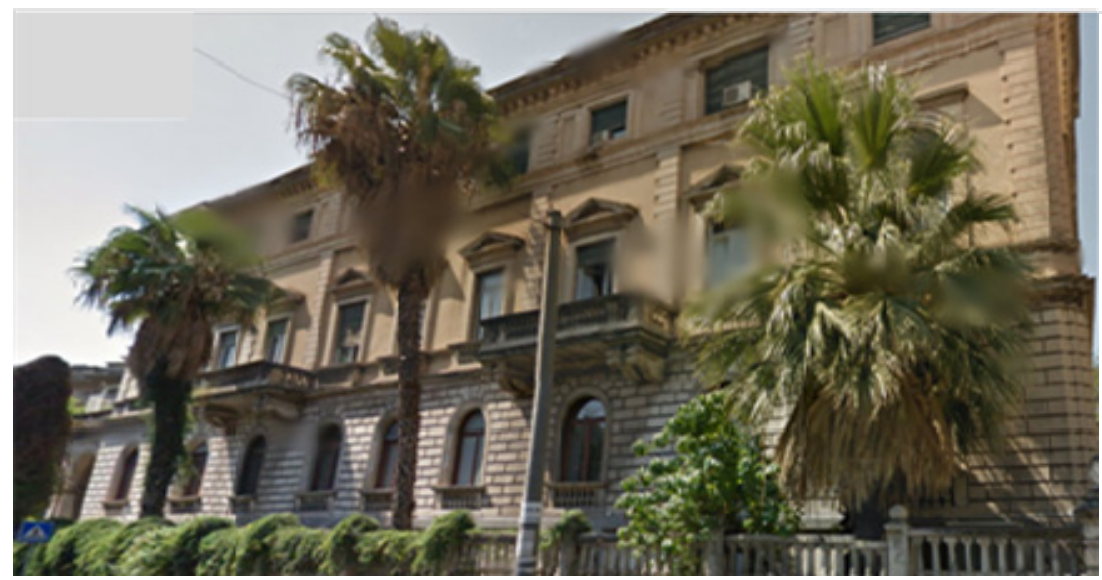

Figure 2: Prospect of the INGV building at the Piazza Roma city centre. 


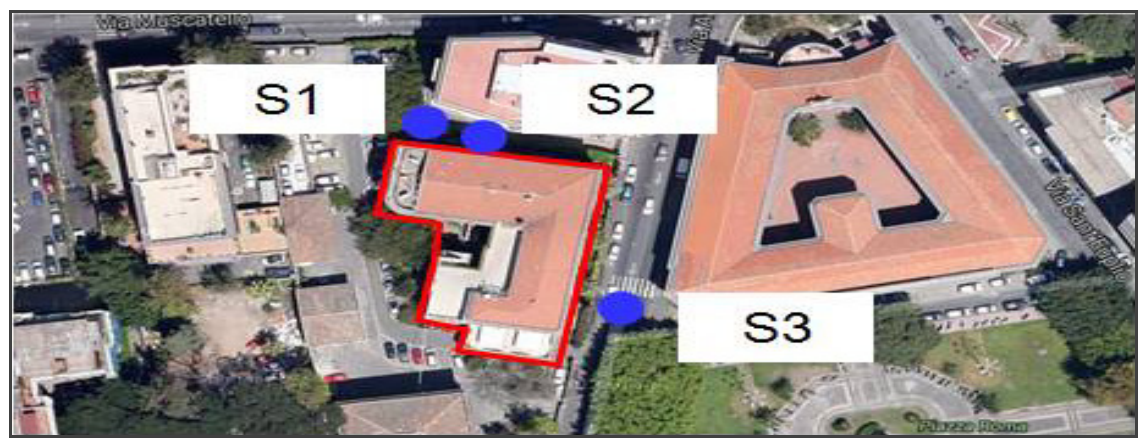

Figure 3: Location of the three boreholes in the Piazza Roma city centre.

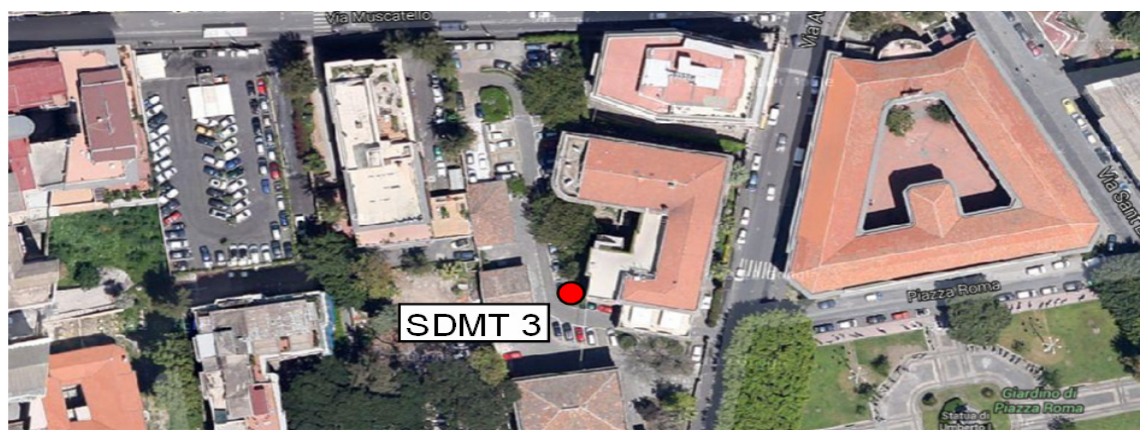

Figure 4: Location of the SDMT in the Piazza Roma city centre.

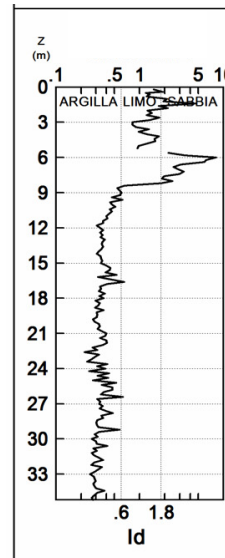

(a)

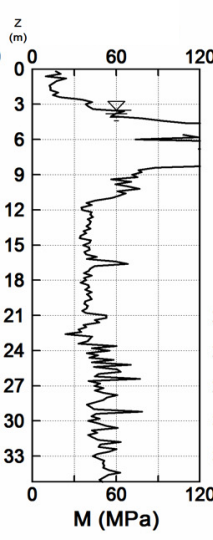

(b)

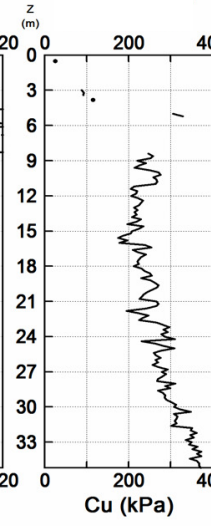

(c)

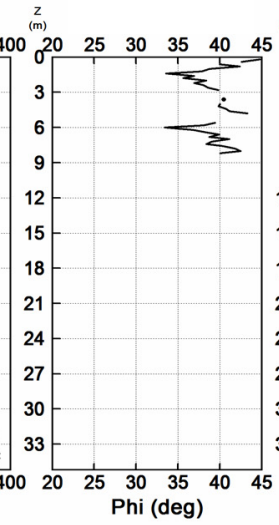

(d)

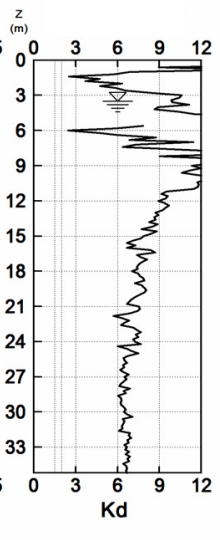

(e)

Figure 5: (a) $\mathrm{I}_{\mathrm{d}}$ : Material Index; (b) $\mathrm{M}$ : Vertical Drained Constrained Modulus; (c) Cu: Undrained Cohesion; (d) Phi: Angle of Shear Resistance; (e) $K_{D}$ : Horizontal Stress Index. 

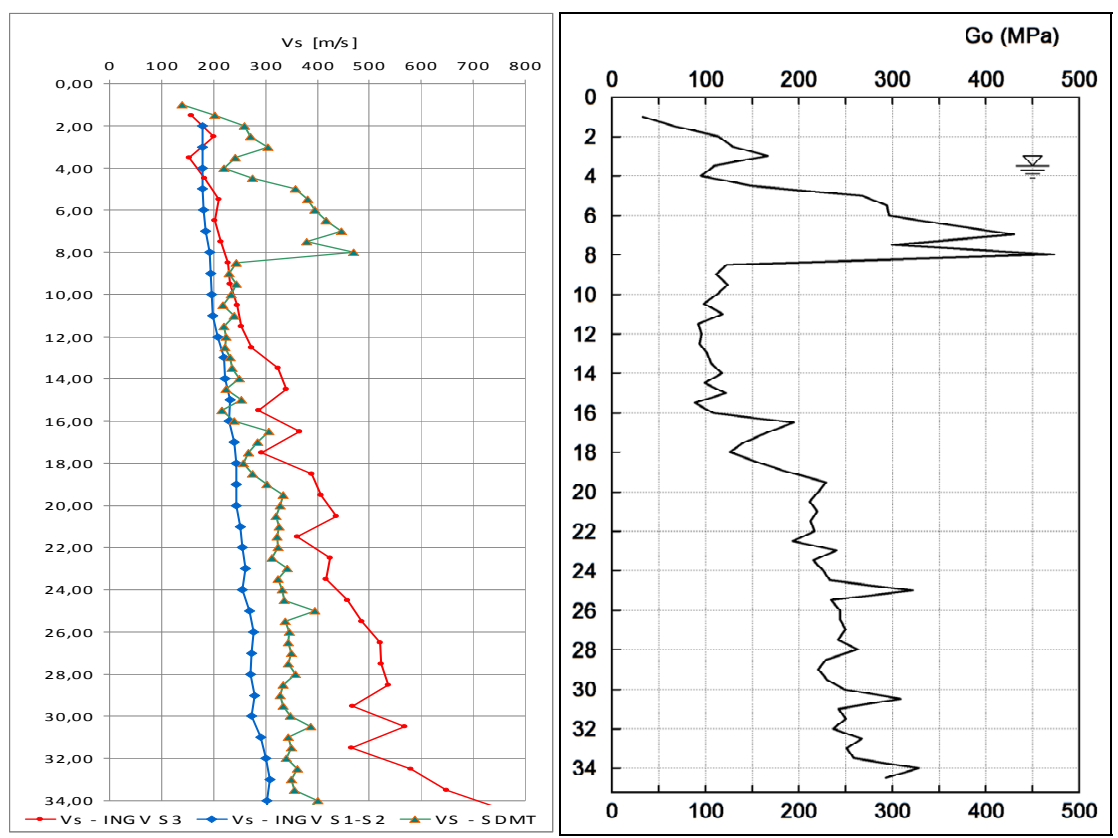

Figure 6: (a) $\mathrm{V}_{\mathrm{s}}$ Shear Wave Velocity; (b) $\mathrm{G}_{0}$ : Small Strain Shear Modulus.

Boreholes S1, S2 and S3 have, respectively, a depth of 60, 80 and $60 \mathrm{~m} .11$ samples have been retrieved starting at the depth of $4.50 \mathrm{~m}$ up to the depth of $72.50 \mathrm{~m}$ from borehole S2. Results of the laboratory tests (Direct shear tests; Triaxial tests) performed on samples show that soils characterised are with values of the angle of shear resistance of about $20^{\circ}-26^{\circ}$.

\section{Shear modulus and damping ratio by laboratory tests}

Shear modulus $\mathrm{G}$ and damping ratio $\mathrm{D}$ of the various lithological deposits were obtained in the laboratory by Resonant Column Tests (RCT) and by Cyclic Loading Torsional Shear Tests (CLTST). Soil nonlinearity can influence significantly seismic response of soil [13-17]; thus it has to be carefully detected. Experimental values of normalized shear modulus $\mathrm{G} / \mathrm{G}_{0}$ (a) and the damping ratio $\mathrm{D}(\mathrm{b})$ versus shear strain observed during resonant column tests and during cyclic loading torsional shear tests on sandy silts with silty clays from INGV site are reported respectively in Figure 7 for the sample retrieved by borehole $\mathrm{S} 1$ at a depth of $4.50 \mathrm{~m}$ and in Figure 8 for the sample retrieved by borehole $\mathrm{S} 2$ at a depth of $14.50 \mathrm{~m}$. The undisturbed specimens have been isotropically reconsolidated to the best estimate of the in situ mean effective stress. The same specimen was first subject to RCT, then to CLTST after a rest period of $24 \mathrm{hrs}$ with opened drainage. CLTST were performed under stress control condition by applying a torque, with triangular time history, at a frequency of $0.1 \mathrm{~Hz}$. 

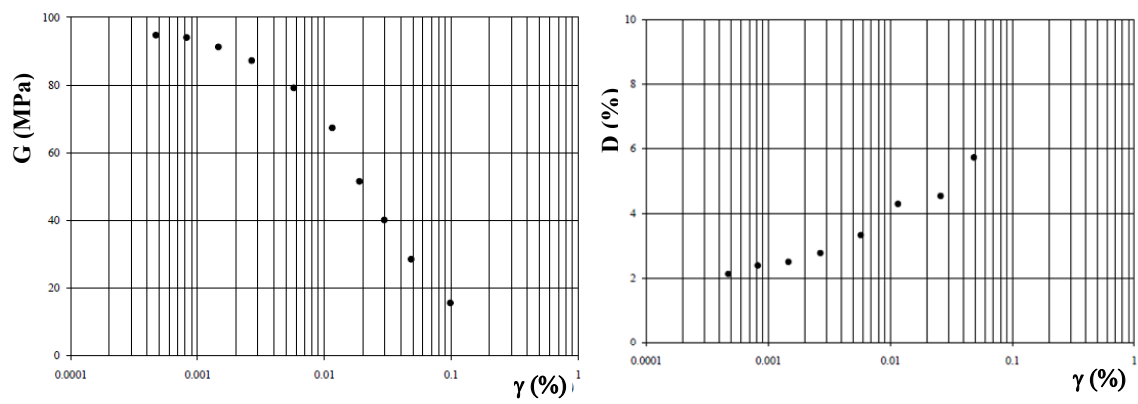

Figure 7: Experimental values of shear modulus G (MPa) and of damping ratio D (\%) versus shear strain for the sample retrieved by borehole $\mathrm{S} 1$ at a depth of $4.50 \mathrm{~m}$.
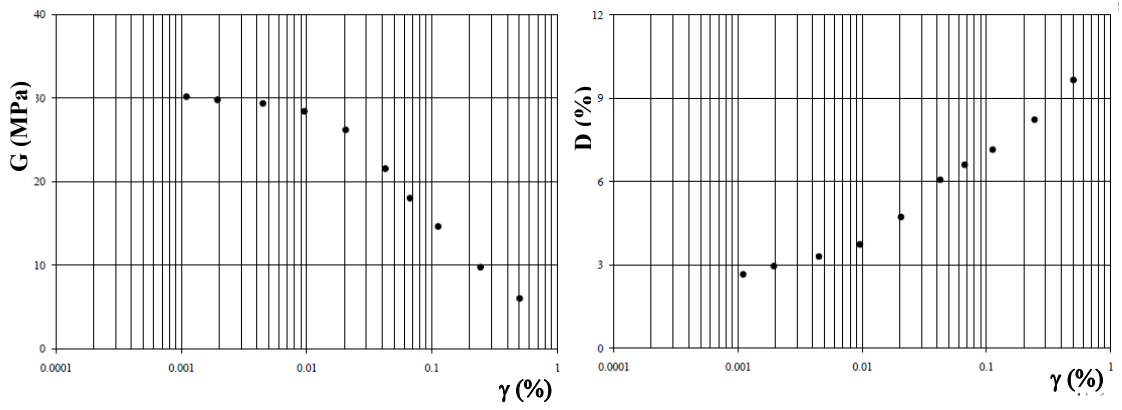

Figure 8: Experimental values of shear modulus G (MPa) and of damping ratio D (\%) versus shear strain for the sample retrieved by borehole $\mathrm{S} 2$ at a depth of $14.50 \mathrm{~m}$.

\section{Seismic acceleration and evaluation of site effects}

Site response analysis, performed by EERA and STRATA codes [18, 19], was carried out by all the normalized shear modulus and damping ratio profiles reported. 1-D columns have respectively a height of $200 \mathrm{~m}$ and of $600 \mathrm{~m}$ and are excited at the base by accelerograms obtained from the synthetic seismograms of 1693 and 1818, with a PGA of $0.207 \mathrm{~g}$ (Figure 9(a)) corresponding to a return period of 475 years in the current Italian regulatory text "seismic hazard and seismic classification criteria for the national territory" obtained by a probabilistic approach in the interactive seismic hazard maps by [20,21]. Further analyses have been performed using scaled seismograms to the maximum PGA of $0.282 \mathrm{~g}$ due to the strategic functions of INGV case study building (corresponding to the return period of 975 years, Figure 9(b)).

Using these time histories, response spectra concerning the investigated site have been deduced. The soil response at the surface was modeled using the Equivalent-linear Earthquake site Response Analyses of Layered Soil Deposits computer codes EERA and STRATA for calculus of amplitude ratios and spectral accelerations. Figure 10 shows the results in terms of maximum 


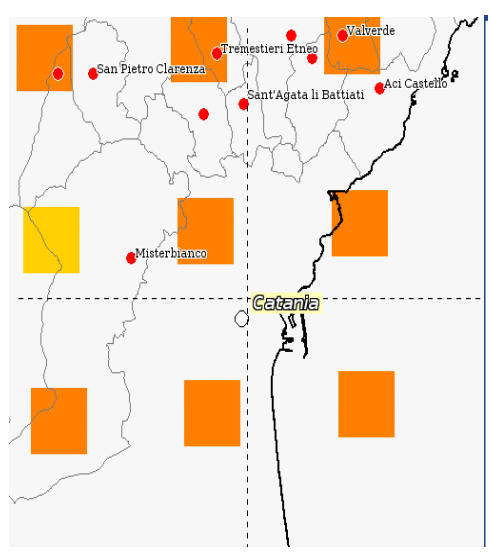

(a)

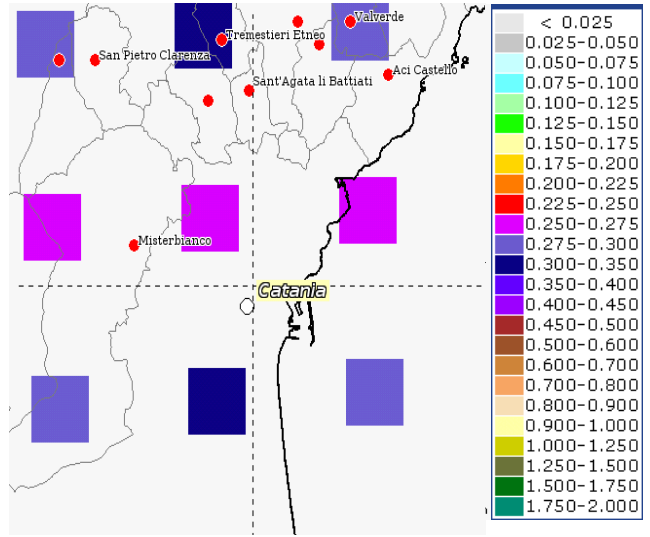

(b)

Figure 9: Interactive seismic hazard map of the city of Catania: (a) 10\% probability of exceedance in 50 years (return period of 475 years); (b) $5 \%$ probability of exceedance in 50 years (return period of 975 years).

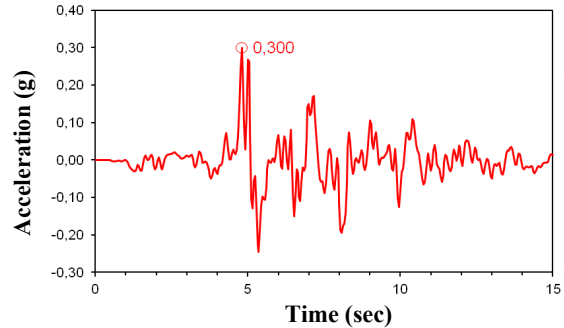

(a)

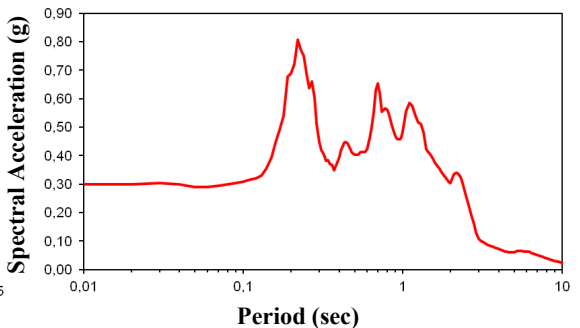

(b)

Figure 10: Results in terms of: (a) maximum accelerations at the surface; (b) response spectrum for the 475 year return period.

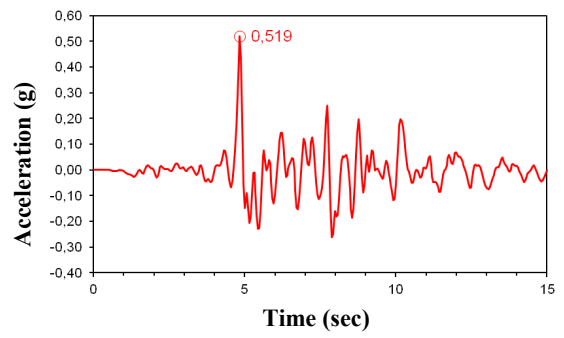

(a)

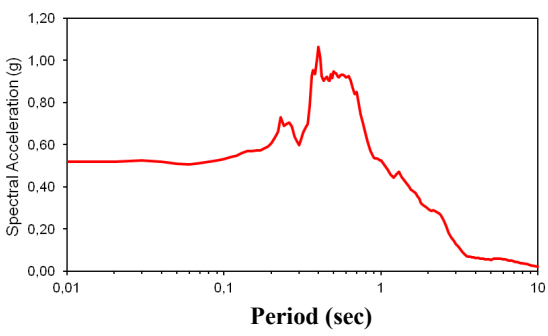

(b)

Figure 11: Results in terms of: (a) maximum accelerations at the surface; (b) response spectrum for the 975 year return period.

accelerations at the surface and in terms of response spectrum for the 475 year return period. Figure 11 shows the results in terms of maximum accelerations at 
the surface and in terms of response spectrum for the 975 year return period. Figs 12 and 13 show, respectively, the response spectra for the 475 and 975 year return period. Results of the site response analysis show high values of soil amplification factors ranging between 1.40 and 1.80 both for the 475 and the 975 year return period of the scenario earthquake. Probably this fact is due to a non linear behaviour of soil that often occur [22], especially in presence of the strong accelerations of the 475 and 975 years of earthquake scenario. High values of soil amplification factors often occur in the city of Catania due to the characteristics of soils, both stratigraphic and topographic and also in other sites [23-36]. The results of the site response analyses have been then used for the evaluation of the Dynamic Soil Structure Interaction (DSSI) [37, 38] of the investigated building area, in terms of the maximum surface acceleration of the scenario earthquake chosen in the analyses.

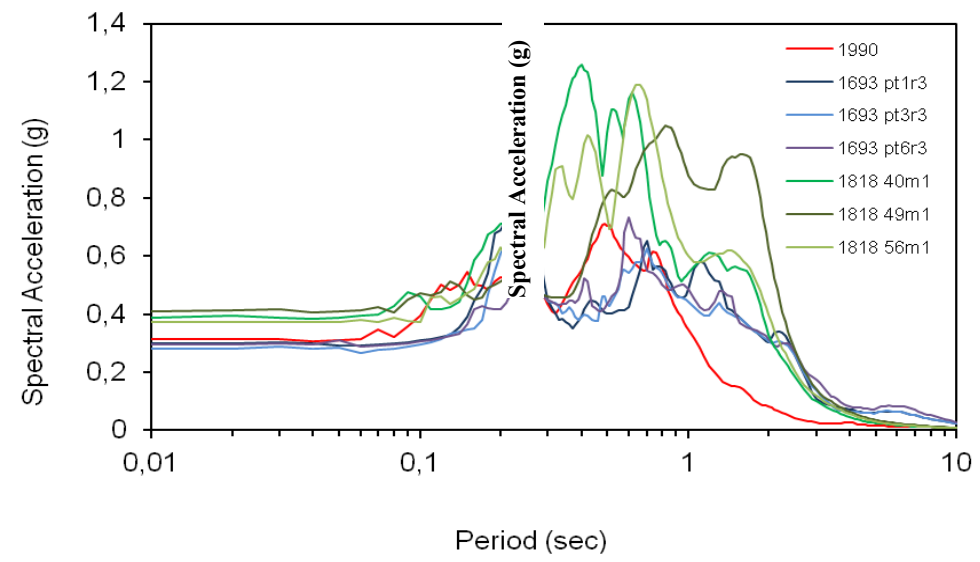

Figure 12: Spectral accelerations obtained for the 475 year return period.

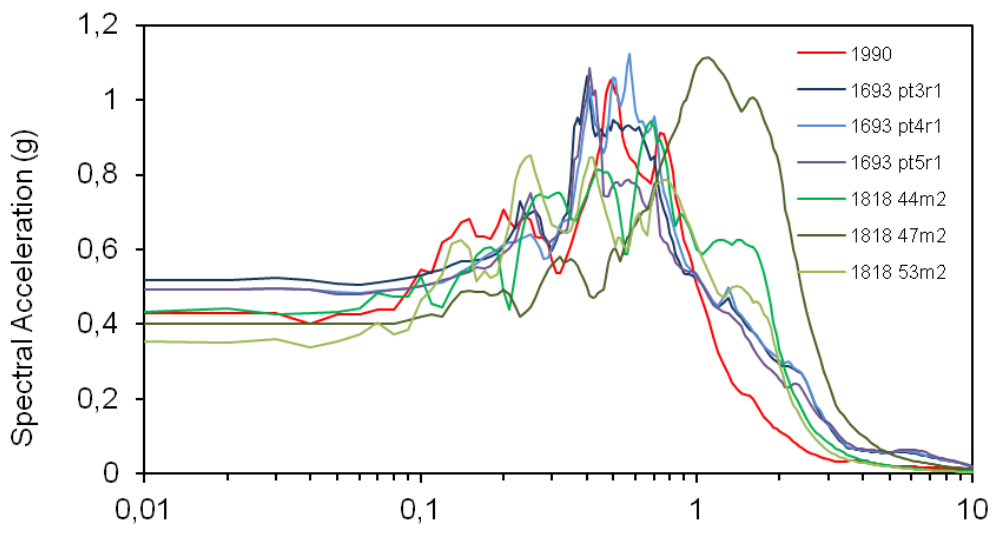

Period (sec)

Figure 13: Spectral accelerations obtained for the 975 year return period. 


\section{Conclusions}

In this paper some information concerning the geotechnical characterisation by SDMT and other tests for the soil response analysis evaluation of the Piazza Roma zone in the city centre of Catania (Italy) have been presented. Local site response analyses have been brought for the Piazza Roma area by 1-D linear equivalent computer codes EERA and STRATA for the evaluation of the amplification factors of the maximum acceleration. High values of soil amplification factors ranging between 1.40 and 1.80 often occur in the city of Catania due to the stratigraphic characteristics of soils, which assume a nonlinear behaviour during shacking.

\section{Acknowledgements}

The authors thanks Michele Maugeri for his invaluable and precious suggestions. This work has been supported by POR FESR Sicilia 2007-2013 under Research Contributions 4.1.1.1 PROT. N. 162 - CUP: G13F12000020004.

\section{References}

[1] Grasso, S., Maugeri, M. (2009). The Road Map for Seismic Risk Analysis in a Mediterranean City. Soil Dynamics and Earthquake Engineering. ISSN: 0267-7261. 29 (6), 2009: 1034-1045.

[2] Grasso, S., Maugeri, M. (2009). The Seismic Microzonation of the City of Catania (Italy) for the Maximum Expected Scenario Earthquake of January 11, 1693, Soil Dynamics and Earthquake Engineering, 29 (6), 2009: 953-962.

[3] Grasso S., Maugeri M. (2012). The Seismic Microzonation of the City of Catania (Italy) for the Etna Scenario Earthquake $(M=6.2)$ of February 20, 1818. Earthquake Spectra. Vol. 28 (2), May 2012, 573-594. ISSN: 87552930.

[4] Monachesi, G. and Stucchi, M. (eds), (2000). DOM4.1: an intensity database of damaging earthquakes in the Italian area, GNDT-CNR open file report, 2 vv., Milano. Web Site: http://emidius.mi.ingv.it/DOM/

[5] Barbano, M.S. (1985). The Val di Noto earthquake of January 11, 1693. In: Postpischl, D. (ed.), Atlas of Isoseismal Maps of Italian Earthquakes, PFG-CNR, Quad. Ric. Scie. 2A, 114, Bologna, 48-49.

[6] Ligresti D., Grasso S. (2009). Historical View of the Damage caused by the 1693 Catania Earthquake and the Reconstruction Activities. In: Proc. First International Conference on Disaster Management and Human Health. New Forest, UK, September 23-25, 2009, 323-331, South: WIT Press, ISBN: 978-1-84564-202-0.

[7] Imposa, S., Lombardo, G. (1985). The Etna earthquake of February 20, 1818. In: Postpischl, D. (ed), Atlas of Isoseismal Maps of Italian Earthquakes, PFG-CNR, Quad. Ric. Scie. 2A, 114, Bologna, 80-81. 
[8] Marchetti, S. (1980). In Situ Tests by Flat Dilatometer. Journ. of the Geotech Eng Div., ASCE, Vol. 106, N. GT3, March, 1980, pp. 299-321.

[9] Marchetti S., Monaco P., Totani G., Marchetti D. (2008). In Situ Tests by Seismic Dilatometer (SDMT). In: "From Research to Practice in Geotechnical Engineering”, ASCE Geotech. Spec. Publ. No. 180 Honouring John H. Schmertmann, 292-311.

[10] Monaco P., Marchetti S., Totani G., Marchetti D. (2009). Interrelationship between Small Strain Modulus Go and Operative Modulus. In: Kokusho, Tsukamoto and Yoshimine (eds), Proc. Int. Conference on PerformanceBased Design in Earthquake Geotechnical Engineering (IS-Tokyo 2009), Tsukuba, Japan, June 15-17, 1315-1323, Taylor \& Francis Group, London.

[11] Martin, G.K. and Mayne, P.W. (1997). Seismic Flat Dilatometer Tests in Connecticut Valley Varved Clay. ASTM Geotech. Testing J., 20 (3), pp. 357-361.

[12] Martin, G.K. and Mayne, P.W. (1998). Seismic Flat Dilatometer in Piedmont Residual Soils. In P.K. Robertson and P.W. Mayne (eds), Proc. 1st Int. Conf. on Site Charact., Atlanta, 2, 837-843. Rotterdam: Balkema.

[13] Abate G., Caruso C., Massimino M.R., Maugeri M. (2008). Evaluation of shallow foundation settlements by an elasto-plastic kinematic-isotropic hardening numerical model for granular soil. Geomechanics and Geoengineering Journal. vol. 3 (1), 27-40 ISSN: 1748-6025. DOI: $10.1080 / 17486020701862174$.

[14] Biondi G., Massimino M.R., Maugeri M. 2014. Influence of frequency content and amplitude of input motion in DSSI investigated by shaking table tests. Bulletin of Earthquake Eng. DOI: 10.1007/s10518-014-9696-8.

[15] Campione F., Capilleri P., Massimino M.R., Maugeri M. (2013). Terremoto dell'Emilia Romagna 2012: risposta sismica locale sulla base di prove SDMT. IARG 2013, 16-18 September 2013, Perugia. DOI: 10.13140/2.1.5158.4969. ISBN: 9788890642135.

[16] Campoccia I., Massimino M.R. (2003). Grade-3 microzonation at Noto. In: Maugeri M., Nova R. Geotechnical analysis of seismic vulnerability of monuments and historical sites. pp. 257-286. ISBN: 88-555-2755-X. Bologna: Pàtron Editore.

[17] Capilleri P., Massimino M.R., Maugeri M. (2003). Evaluation of the destructive potential of the 1997-1998 earthquake ground motion in the town of Sellano. Advances in Earthquake Engineering. Vol. 13, 2003, 305-314. 4th Intern. Conf. on Earthq. Resist. Eng. Structures, ERES IV; Ancona; Italy; 22-24 September 2003; Code 63142. ISSN: 1361617X.

[18] Bardet, J.P., Ichii, K., Lin, C.H. (2000). EERA - A computer Program for Equivalent-Linear Earthquake Site Response Analyses of layered Soil Deposits. University of Southern California, Dept of Civil Eng.

[19] Kottke, A..R., Rathje, E.M. (2008). Technical Manual for Strata. PEER Report. Pacific Earthquake. Engineering Research Center College of Engineering. University of California, Berkeley. 
[20] Meletti C., Montaldo V. (2007). Stime di pericolosità sismica per diverse probabilità di superamento in 50 anni: valori di ag. Progetto DPC-INGV S1, Deliverable D2, http://esse1.mi.ingv.it/d2.html

[21] Meletti C., Galadini F., Valensise G., Stucchi M., Basili R., Barba S., Vannucci G., Boschi E. (2008). A seismic source model for the seismic hazard assessment of the Italian territory. Tectonophysics 450, 85-108.

[22] Maugeri M., Simonelli A.L., Ferraro A., Grasso S., Penna A. (2011). Recorded ground motion and site effects evaluation for the April 6, 2009 L'Aquila earthquake. Bull Earthquake Eng (2011) 9, 157-179. DOI 10.1007/s10518-010-9239-x. ISSN: 1570-761X (print version), ISSN: 1573-1456 (electronic version).

[23] Cavallaro, A., Ferraro, A., Grasso, S., Maugeri, M. (2012). Topographic effects of the Monte Po hill in Catania (Italy). Soil Dynamics and Earthquake Engineering. ISSN: 0267-7261. Vol. 43 (2012): 97-113.

[24] Ferraro A., Grasso S., Maugeri M. (2009). Seismic Vulnerability of a slope in Central Italy. In: Proc. First International Conference on Disaster Management and Human Health. New Forest, UK, September 23-25, 2009, 45-356, Southampton: WIT Press, ISBN: 978-1-84564-202-0.

[25] Grasso S., Maugeri M. (2009). The Road Map for the Seismic Geotechnical Vulnerability of Physical Environment. In: Proc. First International Conference on Disaster Management and Human Health. New Forest, UK, Sept. 23-25, 2009, 333-344, Southampton: WIT Press, ISBN: 978-1-84564-202-0.

[26] Cavallaro A., Ferraro A., Grasso S., Maugeri M. (2008). Site Response Analysis of the Monte Po Hill in the City of Catania. In: 2008 Seismic Engineering Conference Commemorating the 1908 Messina and Reggio Calabria Earthquake. Messina and Reggio Calabria, July 8-11, 2008, 240251, ISBN: 978-0-7354-0542-4.

[27] Monaco P., Santucci De Magistris F., Grasso S., Marchetti S., Maugeri M., Totani G. (2011). Analysis of the liquefaction phenomena in the village of Vittorito (L'Aquila). Bull Earthquake Eng (2011) 9, 231-261. DOI 10.1007/s10518-010-9228-0. ISSN: 1570-761X (print version), ISSN: 1573-1456 (electronic version).

[28] Grasso S., Maugeri M., Monaco P. (2006). Using Kd And Vs From Seismic Dilatometer (SDMT) For Evaluating Soil Liquefaction. Proc. of the Second Int. Conference on the Flat Dilatometer, Washington, April 25, 2006.

[29] Grasso S., Maugeri M. (2008). The Seismic Dilatometer Marchetti Test (SDMT) for Evaluating Liquefaction Potential under Cyclic Loading. Proc. IV Geotechnical Earthquake Engineering and Soil Dynamics. Sacramento, USA, May 18-22, 2008. Geotechnical Earthquake Engineering and Soil Dynamics IV GSP 181 (C) 2008 ASCE, Geo Institute, ISBN 978-0-7844-0975-6, 15 p.

[30] Cavallaro A, Grasso S, Maugeri M, Motta E. (2012). An innovative lowcost SDMT marine investigation for the evaluation of the liquefaction potential in the Genova harbour, Italy. In: Coutinho \& Mayne (eds) Taylor 
\& Francis Group. International Conference on Geotechnical and Geophysical Site Characterization 4. Porto de Galinhas, Pernambuco Brazil, 18/09/2012, pp. 637-644, ISBN: 9780415621366

[31] Cavallaro A., Grasso S., Maugeri M., Motta E. (2012). Site characterisation by in situ and laboratory tests of the sea bed in the Genova Harbour, Italy. In: Coutinho \& Mayne (eds Taylor \& Francis Group, London. International Conference on Geotechnical and Geophysical Site Characterization 4. Porto de Galinhas, Pernambuco Brazil, 18/09/2012, pp. 415-422, ISBN: 9780415621366.

[32] Maugeri M., Totani G., Monaco P., Grasso S. (2011). Seismic Action to Withstand The Structures: The Case History of 2009 Abruzzo Earthquake. In: Proc. of the Eight International Conference on Earthquake Resistant Engineering Structures. Chianciano Terme, Sept. 7-9, 2011, 3-14, ISBN: 978-1-84564-548-9.

[33] Monaco P., Totani G., Totani F., Grasso S., Maugeri M. (2011). Site Effects and Site Amplification due to the 2009 Abruzzo Earthquake. WIT Transactions on the Built Environment. Volume 120, 2011, pp. 29-40. In: Proc. of the Eight International Conference on Earthquake Resistant Engineering Structures. Chianciano Terme, September 7-9, 2011, 29-40, ISBN: 978-1-84564-548-9.

[34] Cavallaro A., Grasso S., Maugeri M. (2008). Site Response Analysis for Tito Scalo Area (PZ) in the Basilicata Region. In: ASCE, Geo Institute. Geotechnical Special Publication No. 181 Geotechnical Earthquake Engineering and Soil Dynamics IV GSP 181. vol. 181, ASCE, American Society of Civil Engineers, ISBN: 978-0-7844-0975-6.

[35] Maugeri M., Grasso S. (2007). A Road Map for Seismic Prevention of Damage. In: Proc. of Sixth International Conference on Earthquake Resistant Engineering Structures. Bologna, Italy, 11-13 June 2007, Southampton: WIT Press.

[36] Condarelli D, Grasso S, Maugeri M, Langer H, Pitilakis K, Manakou M (2009). A methodology to design bedrock input motion using noise measurements. In: Proc. 17th Int. Conf. on Soil Mechanics and Geotechnical Engineering. Alexandria, Egypt, 5-9 October, 2009, 945948, ISBN: 978-1-60750-031-5, DOI: 10.3233/978-1-60750-031-5-945.

[37] Biondi G., Massimino M.R., Maugeri M. (2015). Influence of frequency content and amplitude of input motion in DSSI investigated by shaking table tests. Bulletin of Earthquake Engineering. ISSN: 1570-761X. DOI: 10.1007/s10518-015-9729-y. Experimental study in the shaking table of the input motion characteristics in the dynamic SSI of a SDOF model. 3 December 2014, 35 p. DOI: 10.1007/s10518-014-9696-8.

[38] Massimino M.R., Maugeri M. (2013). Physical modelling of shaking table tests on dynamic soil-foundation interaction and numerical and analytical simulation. Soil Dynamics and Earthquake Engineering. ISSN: 02677261. Vol. 49 (2013): 01-18. 